\title{
Brussels seeks BSE diagnostic test to screen European catte
}

[PARIS] The European Commission is to spend about ECU 1 million (US\$1.16 million) on organizing a competition to select a diagnostic test for bovine spongiform encephalopathy (BSE) in cattle. This is a preliminary step towards the ultimate goal of being able to screen each of the millions of animals entering Europe's abattoirs.

The move is part of a panoply of measures being considered by Brussels to meet the threat that, although draconian measures in the United Kingdom promise to end the BSE epidemic there, the lack of precautions in several other European countries may be providing a breeding ground for the disease.

For example, although the United Kingdom and France have introduced a blanket ban on the feeding of meat and bone meal to all farm animals, the European Union (EU) has only succeeded in introducing a ban on the feeding of ruminant proteins - in meat and bone meal - to ruminants. Feed must also be heated at $133^{\circ} \mathrm{C}$ for 20 minutes.

The United Kingdom, France and Belgium have also implemented a ban on sheep heads, spinal cords and spleen in the human food chain, but an EU-wide ban has been opposed by Germany and other countries on the grounds that they do not have BSE. Franz Fischler, the EU agriculture commissioner, is likely to resubmit the proposal for such a ban to Europe's farm ministers soon. He will be backed by a report on the risk of BSE in sheep that is scheduled to be adopted this month by the commission's Scientific Steering Committee, the body that oversees all the commission's scientific advisory committees (see Nature 395, 6; 1998).

"The risk of human exposure to BSE is probably higher in those countries which are officially BSE-free, and subsequently take no precautions," says Gérard Pascal, chairman of the committee. He adds that cattle still pose a risk in certain European countries.

Marc Savey, a researcher at the French National Veterinary Centre, points out that the occurrence of sporadic cases of BSE in cattle, despite the ruminant feed ban, shows clearly the existence of cross-contamination with chicken and pig feed, or fraudulent use of such feeds for ruminants. He adds that a blanket ban on the feeding of meat and bone meal to all farm animals is needed to ensure that this source of infection is cut off.

It is in this context that the commission has also launched a programme to develop tests capable of identifying the presence of mammalian proteins in composite feed supposed to be free of such proteins, and of checking that feed has been heated correctly.
The risk is not that of new BSE epidemics on the scale of millions of cases as occurred in the United Kingdom, but that low levels of BSE may persist in European herds, says Pascal. Even with a few hundred cases a year, there is a risk of recycling the disease through feed, and of allowing diseased carcasses to enter the human food chain, says Savey.

"It is impossible that countries such as Germany, Italy and Spain have not had cases," asserts one of the commission's advisers on BSE. Given the flow of contaminated feed and animals in these countries (see Nature 382, 4; 1996), "to believe that BSE suddenly stops at the Franco-German border is scientifically ridiculous".

To counter the threat that BSE might persist in continental Europe, the commission is now giving a "high priority" to a diagnostic test, according to one official. "The commission's aim is to have a test applicable to every animal arriving at the abattoir," says Pascal, adding that the test must detect animals that have BSE but do not show clinical symptoms.

In a related move, the UK government's Spongiform Encephalopathy Advisory Committee last week recommended surveying more than 1,000 cattle brains from slaughtered animals to see if they are harbouring BSE without showing symptoms, using a test developed by John Collinge at Imperial College School of Medicine in London.

The European Commission's competi- tion for a diagnostic test was launched in July by its consumer directorate (DG24). Each test must have a solid scientific basis, be at an advanced stage of development, and be able to be scaled up quickly for industrial use with millions of cattle, according to an official. The commission expects the competition to be completed by the end of the year.

Under the blind-study protocol, the winners will be sent thousands of coded samples of cattle brain and other tissues, but will not be told which are infected. Four out of 10 applicants have now been selected.

Commission officials declined to identify the winners, but the Zurich-based biotechnology company, Prionics, this week confirmed that it has been selected. A pilot study of the Prionics test (see Nature 390, 74; 1997), in screening 3,000 cattle from Swiss slaughterhouses, was approved by Swiss veterinary authorities last month, and the results are expected at the end of this month.

Another likely candidate is the Irish company Enfer Scientific which has licensed technology from the UK company Proteus for the development of a post-mortem test of BSE in cattle. The Proteus technology is also being studied by the UK Public Health Laboratory Service, as a potential diagnostic test for Creutzfeldt-Jakob disease in humans.

Current tests for BSE are based on the use of antibodies to detect the presence of the abnormal prion proteins that accumulate in

\section{Don't copy our clone, say Dolly scientists}

[LONDON] Pictorial — as well as physical copies of Dolly the cloned sheep (right with 'foster mother') will in future need special permission following a decision by the Roslin Institute in Scotland to apply for trademark protection to control the use of her picture in advertising.

The decision was made after Zanussi, the electrical appliances manufacturer, used a picture of a sheep in an advertisement with the title: "The misappliance of science".

But the advertisement may not have had the desired impact. Surprisingly, almost half of those responding to a UK-wide survey whose results were released this week said they had not heard of Dolly.

But, when given a series of six possible options, two-thirds of the survey respondents correctly answered that Dolly was the first mammal cloned from an adult cell. Some 49 per cent of respondents thought that Dolly had been cloned to "advance human cloning", a goal approved

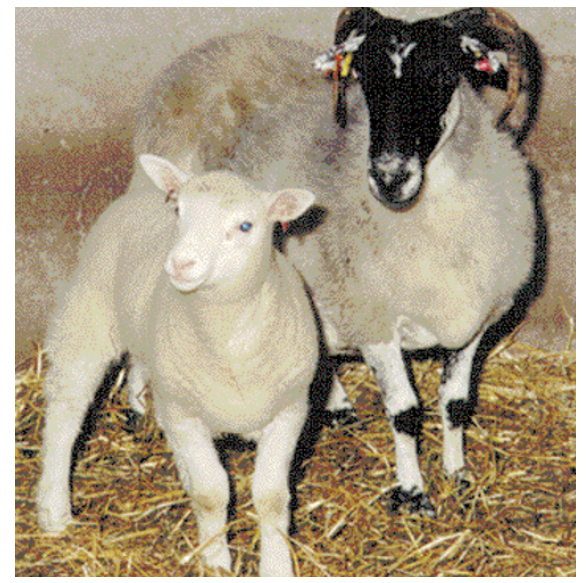

of by only 11 per cent of those questioned.

Although most respondents approved of biotechnology to develop medicines, only 17 per cent approved of genetically modified food. The survey was carried out by the public relations consultancy HCC-De Facto Group.

Ehsan Masood 
infected tissues and cause the clinical symptoms of spongiform encephalopathies. Bruno Oesch, from Prionics, claims its test is "99.9 per cent specific", and says that the company has reduced the time from processing samples to obtaining results to six hours.

But several scientists are sceptical of the performance of all the tests being developed, arguing that there remains uncertainty about their specificity and sensitivity.

Diagnosing spongiform encephalo-

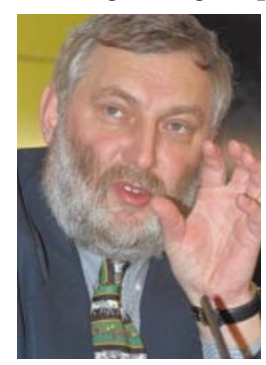

pathies is intrinsically difficult, compared with an AIDS test for example, where the presence of antibodies to HIV clearly indicates the presence of the virus. Abnormal prions may only be present in animals at a relatively Fischler: weighing BSE risk in sheep. late stage, so detecting their absence may not guarantee that the animal is not sick, argue several scientists.

They claim that, whereas tests may be able to detect BSE in sick animals, so far no published data provide convincing proof that tests could reliably detect preclinical cases. The commission's ambition of testing millions of cattle is "very premature", says one.

Despite these limitations, the potential of a test as a tool for managing BSE is "so great that the commission has put a very high priority on it," according to one official from the commission's consumer directorate.

To put pressure on BSE-free countries to accept stricter precautions, the commission has set up an expert panel to prepare a "geographical risk assessment" of BSE in Europe. This will construct mathematical models of risk based, for example, on feed use, imports and farming practices. Using such a model, Germany, currently listed as BSE-free, would probably be reclassified as 'at risk' from BSE, says one commission official. Declan Butler

\section{Cuts 'could leave energy department brain-dead'}

[WASHINGTON] The US Department of Energy (DOE) is facing a crisis in overseeing its research programmes as its most experienced technical staff leave and others await retirement, according to senior officials.

Almost half of the DOE's 500 technical managers - who oversee billions of dollars worth of research programmes from its Washington headquarters - will be eligible for retirement in the next five years, according to a report presented last week to the department's Laboratory Operations Board.

"The technical managers are overwhelmed and discouraged about the future," says David Crandall, manager of the inertial confinement fusion programme and cochair of the panel that produced the report.

"Due to continued downsizing, without concomitant reduction in programmes, those who remain are overwhelmed with work and often exhausted," the report says. It also warns that the "pipeline" of younger people to become research managers at the department "is virtually empty".

The energy department has been under heavy pressure to reduce its staffing levels since 1995, when the then newly elected Republican Congress threatened to abolish it outright. Hazel O'Leary, then energy secretary, responded to this threat by proposing a Strategic Alignment Initiative (SAI), which committed all sections of the department to meet fixed targets for staff reductions.

As a result, the department is unable to replace people who leave, including the technical managers who are supposed to supervise its physics, nuclear weapons and other energy-related research programmes.

"The department has a potential crisis within five years, in which time it will go brain-dead," asserts Richard Hopf, a deputy assistant secretary for procurement.

At the meeting of the Laboratory Operations Board in Washington on 9 September, other senior officials said they were already aware of the problems raised by the report.

Victor Reis, for example, assistant secretary for defence programmes, said the nuclear weapons stewardship programme has a dozen technical management positions that have gone unfilled for a year because of the SAI targets. "Everybody just took a proportional cut" in staff numbers, Reis said. "It wasn't related to the job that had to be done."

John McTague, co-chairman of the Laboratory Operations Board, who is a vice-president of Ford and once served as science adviser to George Bush when he was US president, pointed out that the issue of attracting good people to work for the federal government was a perennial one.

But Martha Krebs, assistant secretary for energy research, echoed Reis's frustration with the current logjam.

According to Crandall's report, the problem of retiring staff is most acute in Krebs's office, which overseas $\$ 2$ billion worth of research in physics and basic science. Of 102 technical managers at the office in 1995, 14 have already left and another 33 will be eligible to retire by the end of this year. Krebs says the root of the problem lies with Congress, where appropriations committees have demanded staff cuts and tried to block efforts to second technical staff from the laboratories to the department's headquarters.

But staff at the committees claim that although the department was invited to propose a plan that would enable it to fill key positions, it has failed to do so. Colin Macilwain

\section{Biology teaching wins $\$ 90 \mathrm{~m}$ boost from Howard Hughes institute}

[WASHINGTON] The Howard Hughes Medical Institute (HHMI) has awarded \$90 million in grants to support the development of undergraduate education in biology at 58 US universities.

The money - the largest-ever tranche of education funding from the institute - is intended to help the universities to introduce undergraduates to research, to update undergraduate science courses, and to build outreach programmes with local schools and community colleges.

Joseph Perpich, HHMI's vice-president for grants, says the money will encourage improvements to undergraduate education at a time when major research universities have been criticized for neglecting it.
A commission established by Ernest Boyer, the late president of the Carnegie Foundation, reported earlier this year that many leading research universities were failing to teach undergraduates what research was, or to let them do any of it (see Nature 392, 746; 1998).

Perpich says that the 58 universities selected by HHMI for support from 191 applicants "have a strong commitment to undergraduate science education". He adds that the Boyer report "didn't reflect what's happening at these institutions".

At Cornell University in New York State, for example, a \$2.2 million grant will support undergraduates doing laboratory research, and help to continue an outreach programme to high school biology teachers. Peter Bruns, director of the Cornell programme, says undergraduates will be exposed to laboratory practice on several levels as a result of the grant. All 1,000 students on an introductory course in biology will spend a short time in a research lab. Three hundred of the students will also have the chance to conduct independent research, and 70 will receive a stipend to spend a summer with a mentor in the lab.

But Bruns says the overall picture for undergraduate education remains "mixed" at Cornell and other research universities. He thinks many institutions "have not come to grips with the issue" of undergraduate science education. 